\title{
India-Bhutan Relationships: Cordial but Concerns Remain
}

Amit Ranjan*

\begin{abstract}
In 2018 India and Bhutan completed 50 years of their diplomatic relationships. For a large number of South Asian observers and commentators, the two countries are considered close to each other, however, there are areas of concern. One of them is India's investments in Bhutan's hydropower sector. There is a growing disillusionment among a section of the Bhutanese population over India's engagements in this sector. This paper looks at the relationships between the two countries and examines the concerns of Bhutanese against India. The author argues that Bhutan is a small but strategically important country for India whose concerns must be satisfactorily addressed by New Delhi.
\end{abstract}

Keywords: China, Doklam, Friendship Treaty, Hydropower, Royal Monetary Authority

\section{Introduction}

As a small neighbouring country, Bhutan does not attract significant attention in India. This statement can be substantiated by looking at the number of articles and commentaries on Bhutan published in the journals, newspapers and websites run from India. The situation is such even though after assuming the office in 2014, the Indian Prime Minister, Narendra Modi paid his first bilateral foreign visit to Bhutan. During his visit, he inaugurated India funded Supreme Court building in the country and held bilateral

* Visiting Research Fellow at Institute of South Asian Studies, National University of Singapore, Singapore; amitranjan.jnu@gmail.com 
dialogue with the King and the prime minister of the country. Since then there has been several bilateral visits of the political leaders to each other's countries. In recent years only time the country received due attention from Indian media and, a few of the Indian strategist thinkers was during the Doklam/Doko-La or Donglang crisis in 2017 when India and China engaged in a military stand-off for 73 days in a territory in Bhutan.

Politically, India and Bhutan share very close relationships. However, over the years, differences have emerged between the two countries on certain issues. One of them is India's investments in Bhutan's hydropower sector. A section of Bhutanese accuses India for exploitation of their hydro electricity for its own benefit and pushing the country into hydro debt trap. This paper looks at the bilateral relationships between India and Bhutan and examines some of the concerns of Bhutanese against India. Besides the introduction and conclusion, this paper is divided into three parts. The first part discusses the history of India-Bhutan relationships. The second part looks at the political development after Doklam military stand-off. The final section examines India's investment in Bhutan's hydropower sector which has disillusioned a section of Bhutanese. Some of the views expressed in this paper and contents have been earlier published in form of commentaries (See Ranjan, 2018a, Ranjan, 2018b and Ranjan \& Ravindran, 2018).

\section{History of India-Bhutan Relations}

India-Bhutan relationships dates to ancient times. For the Bhutanese, India is gyagar (the holy land) because Buddhism which is being practised by almost all of them was born in India. In eighth century AD, an Indian monk named Padmasambhava arrived in Bhutan to teach tenets of Buddhism. He was from Uddiyyana (present-day in Swat valley in Khyber Pakhtunkhwa in Pakistan) and was regarded as the third Buddha in the Vajrayana tradition (Stobdan, 2017). In Bhutan, he is popularly known as Guru Rinpoche. It is believed that through his spiritual powers, Padmasambhava had subdued all hostile spirits and divinities from Tibet who posed threats to the Himalayan kingdom (Karma, 2013, p. 89). 
In the medieval period especially after Bengal came under the control of the Mughals (1526-1857) in 1576, confrontations between the local Mughal governors and the Bhutanese administrators to control the fertile plains of Bengal was a regular affair. After consolidation of Aurangzeb's reign (1658-1707) over India, Mughal commander, Mir Jumla was sent to capture Cooch Behar and punish King Pran Narayan. To protect himself, the King fled to Bhutan. Pran Naryan's asylum in Bhutan led to Bhutanese involvement in the affairs of Cooch Behar in following years (Ibid). After the death of Aurangzeb in 1707 the Mughal power weakened. This helped the Bhutanese to solidify further their supremacy over Cooch Behar. In 1750s, Bhutan appointed a de-facto viceroy and garrisoned forces in Cooch Behar. In 1765, once again the Bhutanese interfered in Cooch Behar's affairs to prevent a possible coup in the state (Karthikeyan, 2017).

In 1764 after the victory in Battle of Buxar the East India Company formally occupied Bengal and Bihar. During the Company's rule in India, there were frequent skirmishes between the Bhutanese and the East Indian Company's army over duars (fertile land in rivers Brahmaputra and Ganga region in Assam and Bengal). To engage with Bhutan, in the 1770s and 1780s a number of missions were sent to Bhutan by Governor-General Warren Hastings (Robinson, 1989). However, peace could not be made. Later, the two sides fought a war in 1773 in which the East India Company's troops defeated the Bhutanese army. Afterwards, the two sides signed a treaty of peace and commerce in 1774 (Kohli, 1993). But peace was established only after the signing of the Treaty of Sinchula between Bhutan and British India in November 1865. Under this treaty, Bhutan ceded a part of Assam and Bengal duars and about eightythree square kilometres of territory in south eastern Bhutan to British India. This was in return of an annual subsidy of 50,000 rupees.

In 1910, notably, to counter the China's charges in Bhutanese territory, the treaty of Punakha was signed between Bhutan and British India. Under this treaty, the British agreed to not interfere in the internal affairs of Bhutan to which the Bhutanese agreed 'to be guided by the advice of India in regard to its foreign relations' (Robinson, 1989, p. 164). The treaty of Punakha was not a stand- 
alone document but a modification of the treaty of Sinchula which the two sides signed in 1865. Since then, although the term 'protectorate' has never been used by the British to describe their relationship with Bhutan, the country was almost treated as such.

After independence from the British rule in 1947, India emerged as its successor state. To keep Bhutan on its side, India signed the treaty of Friendship with Bhutan in 1949. In 1968, diplomatic relationship between India and Bhutan was established with an appointment of a resident representative of India in Thimphu. Prior to it, a political officer in charge of Sikkim ${ }^{1}$ also oversaw India's Bhutan relations (Ministry of External Affairs, Government of India, 2012). In the late 1960s, 70s and 80s there were moments when it seemed that Bhutan was all set to drift from India. For example, in 1968, Bhutan barred unauthorized foreigners, including Indians, from entering its territory. A year later in 1969, Bhutan also started its own currency (Shubham, 2014). In 1970, after setting up its ministry for foreign affairs, Bhutan tried to have an independent foreign policy. In 1978, the Bhutan Mission in India was renamed as the Royal Bhutanese Embassy. This was seen by India as a diversion from the spirit and letters of the 1949 treaty (Ibid). In 1984 Bhutan began boundary related talks with China. It also reduced India's annual assistance to Bhutan by 43 per cent and started looking for other international donors (Ibid).

After a short period of political anxiety, India-Bhutan relations were put on tracks in late 1980s. In 1988 then President of India, R. Venkatraman paid a visit to Bhutan. Before him in 1985 and again in 1988, then Prime Minister of India, Rajiv Gandhi visited Bhutan (Ministry of External Affairs, Government of India, 2012). In the 1990s, India aided infrastructure projects in Bhutan. For example, in 1995, work on Kurichhu hydro project began with 60 percent grant and 40 percent loan by India to Bhutan. Then in 1997 works on the Tala Project began with 60 percent grant and 40 percent loan by India (Economic and Political Relations between Bhutan and Neighbouring Countries, 2013)

In 2007, the India-Bhutan friendship treaty was updated. Article 2 of the 1949 treaty states that "The Government of India undertakes to exercise no interference in the internal administration of Bhutan. On its part, the Government of Bhutan agrees to be guided by the 90 
advice of the Government of India in regard to its external relations" (Ministry of External Affairs, Government of India, 2007). Under Article 6 of the 1949 treaty, Bhutan had to obtain permission from India over matters of arms import. 2007 updates have relieved Bhutan from both. Article 2 of the 2007 updated treaty states that "neither Government shall allow the use of its territory for activities harmful to the national security and interest of the other" (Ibid). On security front, Article 4 of the treaty states that "The Government of India agrees that the Government of Bhutan shall be free to import, from or through India into Bhutan, whatever arms, ammunition, machinery, warlike material or stores as may be required or desired for the strength and welfare of Bhutan, and that this arrangement shall hold good for all time as long as the Government of India is satisfied that the intentions of the Government of Bhutan are friendly and that there is no danger to India from such importations. The Government of Bhutan agrees that there shall be no export of such arms, ammunition and materials outside Bhutan either by the Government of Bhutan or by private individuals" (Ibid). Then Article 3 and 8 of the treaty calls on for having free trade and commerce, and consolidation of economic relationships between the two countries (Ibid).

Earlier to address India's concern, in 2003 the Royal Bhutan Army carried out Operation All Clear to flush out the United Liberation Front of Assam and Bodo militants taking shelter in Bhutan (The Bhutanese, 2015). Unfortunately, most of the Indian media incorrectly showed that the operation was carried out by the Indian security forces (Ibid). After the update of the India-Bhutan friendship treaty, then Indian Prime Minister Dr Manmohan Singh visited Bhutan in 2008. At that time India agreed to let Bhutan have 16 entry and exit points to facilitate trade and commerce with other countries except China. In 2014, soon after taking the office, Modi paid visit to Bhutan. In 2016 India and Bhutan signed an agreement on Trade, Commerce and Transit between the two countries.

\section{Post-Doklam Developments in India-Bhutan Relations}

There is a growing shadow of China on India-Bhutan relationships. Historically, in 1971 Bhutan voted in favour of the People' Republic of China's membership to the United Nations. ${ }^{2}$ In 1979, China and 
Bhutan decided to have a direct negotiations on their border issues (Mathou, 2004). The first round of boundary talks was held in Beijing in April 1984. From 1994, Chinese ambassadors to India have been paying working visits to Bhutan. Since 1995, Bhutan has been "supporting (the) one-China policy" (Ibid). In 1998 Bhutan and China signed an agreement on the Maintenance of Peace and Tranquility Along the Sino-Bhutanese Border Areas. The two sides accepted that they have reached an agreement and agreed to work in accordance with the five principles of mutual respect for each other's sovereignty and territorial integrity, mutual non-aggression, mutual non-interference in each other's internal affairs and peaceful co-existence and for the purpose of maintaining peace and tranquillity along the Sino-Bhutanese border. In 2015, the 23rd round of talks was held in Thimphu and, in 2016, technical expert groups from the two countries met in Bhutan (Ministry of Foreign Affairs, Government of Bhutan, 2016).

Despite agreement and on-going talks on border, in 2017 a military stand-off took place between India and China when China laid a territorial claim over Doklam in Bhutan. Doklam is a plateau of approximately 89 square kilometres, which lies at the tri-junction of India, China and Bhutan. It is close to India's 'Chicken's Neck', the Siliguri Corridor. The stand-off remained for about 73 days, following which India and China agreed to disengage their personnel from that site on 28 August 2017 (Ministry of External Affairs, Government of India, 2017).

Earlier, on 29 June 2017, in a press release, the Bhutanese government stated:

Boundary talks are ongoing between Bhutan and China and we have written agreements of 1988 and 1998 stating that the two sides agree to maintain peace and tranquillity in their border areas pending a final settlement on the boundary question, and to maintain status quo on the boundary as before March 1959. The agreements also state that the two sides will refrain from taking unilateral action, or use of force, to change the status quo of the boundary. Bhutan has conveyed to the Chinese side, both on the ground and through the diplomatic 
channel, that the construction of the road inside Bhutanese territory is a direct violation of the agreements and affects the process of demarcating the boundary between our two countries. Bhutan hopes that the status quo in the Doklam area will be maintained as before 16 June 2017. (Ministry of Foreign Affairs, Royal Government of Bhutan, 2017)

Soon after the military disengagements at Doklam, India decided to open Bhutanese consulate at Guwahati in 2018. In another significant development after the Doklam military stand-off, Assistant Foreign Minister of China, Kong Xuanyou, visited Bhutan from 22 to 24 July 2018. He was accompanied by Luo Zhaohui, the Chinese Ambassador to India. In Bhutan, the Assistant Foreign Minister met the fifth king, Jigme Khesar Namgyel Wangchuck, the fourth king, Jigme Singye Wangchuck, and Tobgay (Ministry of Foreign Affairs of the People's Republic of China, 2018). During the meetings, the Chinese Assistant Foreign Minister stated, that

the Chinese side is willing to work with the Bhutanese side to maintain high-level contacts, expand practical cooperation, and strengthen multilateral communication and coordination, so as to achieve common development on the basis of mutual respect, mutual benefit and win-win results. The Chinese side welcomes Bhutan to actively participate in the Belt and Road Initiative and share China's development dividend. Both sides should continue to promote the boundary negotiations, abide by the already-reached principles and consensus, and jointly maintain peace and tranquillity in boarder areas so as to create positive conditions for the final settlement of the boundary issue (Ibid).

On its part, the Bhutanese side expressed that

although China and Bhutan have not formally established diplomatic relations, the two countries have enjoyed a traditional friendship which could be regarded as a model between big countries and 
small countries. The Bhutanese side admires the development achievements of China and welcomes the positive outcomes of the Belt and Road Initiative proposed by President Xi Jinping...Bhutan firmly adheres to the one-China policy and is committed to deepening exchanges and cooperation with China and stands ready to maintain communication with the Chinese side on bilateral relations and the boundary issue (Ibid).

About the Chinese Assistant Foreign Minister's visit to Bhutan, Thimpu kept New Delhi "in the loop" (Roy, 2018). However, India remains cautious about any such visits and meetings between the officials from Bhutan and China.

Later, on 15 September 2018, Bhutan had its primary round of polls to choose the next government. The incumbent party failed to qualify for the final round of polls which were held on 18 October 2018. In the elections, the Druk Nyamrup Tshogpa (DNT) party won the elections and its leader Lotay Tshering became the new prime minister of Bhutan. After becoming prime minister, Tshering paid a visit to India from 27 to 29 December 2018. During his visit the two prime ministers"expressed satisfaction at the excellent state of bilateral ties of friendship and cooperation, which are marked by utmost trust, mutual understanding, goodwill, respect for each other's interests, and reinforced by robust people to people linkages and close economic and development partnership" (Ministry of External Affairs, Government of India 2018). The two sides discussed the Government of India's development assistance package for Bhutan's 12th Five Year Plan for the period 1 November 2018 to 31 October 2023. It was conveyed to Bhutan that India will provide grant assistance of Indian Rupees (INR) 4500 Crore towards Bhutan's 12th Five Year Plan, and a transitional Trade Support Facility of INR 400 Crore over a period of five years to strengthen bilateral trade and economic linkages (Ibid). The two countries reiterated their commitment to jointly develop 10,000 Mega Watt (MW) of hydropower generating capacity in Bhutan. In this regard, the leaders discussed the Sankosh Hydropower Project. They expressed satisfaction at the progress of the 720 MW Mangdechhu hydro-power project in Bhutan (Ibid). The leaders 
welcomed the mutually beneficial understanding reached between the two sides on the tariff for the export of surplus power from Mangdechhu project in Bhutan to India (Ibid).

\section{Areas of Concern}

Despite historical relationships the two countries share, there are areas of concern which have disillusioned a section of the population against India. This is clearly visible in India's hydropower investments in Bhutan. India's assistance to Bhutan started in 1961. Later in 2006, the two countries signed a comprehensive agreement in the hydropower sector. An additional protocol to the 2006 agreement was signed in March 2009. Under the additional protocol, India agreed to assist Bhutan in developing a minimum of 10,000MW of hydropower by 2020 . India also agreed to import surplus amount of electricity from those hydro projects (Ministry of External Affairs, Government of India, 2018). Earlier, the projected capacity was 5,000 megawatts. This estimate was doubled after the visit by then-Indian Prime Minister, Dr Manmohan Singh, to Thimphu in 2008. The objective behind the agreement was to make Bhutan a self-sufficient country in electric generation and to help the country reduce its trade deficit with India (Tala Hydroelectric Project, 2018).

The format of the 2006 hydropower agreement is similar to the 1,020 MW Tala hydropower project agreement between the two countries. The Tala hydroelectric project is the largest functional hydropower project in Bhutan. Work on this project began in 1998 and it was commissioned in 2008. India's assistance for Tala came in the form of 60 per cent grant and 40 per cent loan, with an interest rate of nine per cent per annum (Ibid). Indian companies Bharat Heavy Electrical Limited of India, Hindustan Construction Company, Larsen and Tubro and Jaiprakash Industries participated in the Tala contract (Lamsang, 2017).

Bhutanese complain that India buys cheap electricity from the hydroelectric projects in Bhutan. For example, in 2017, the tariff rate on the import of hydroelectricity from the Tala hydroelectric project by India was 1.80 Bhutanese Ngultrum (BTN). This was much below the domestic market price in India which was around 
₹7 to ₹8 per unit (Ibid). In July 2017, Bhutan proposed a tariff hike from the Chukha hydropower project. The last hike was made in 2014 when the tariff rate was raised from BTN 2 per unit to BTN 2.25per unit. Bhutan's proposal to raise the tariff was accepted, in principle, by India (Outlook, 2017).

Almost all hydropower projects take more than the needed time to start operation. Such delays add debt burden to Bhutan because the loan granted by India to Bhutan keeps on charging 10 per cent ${ }^{3}$ every year (Tala Hydroelectric Project, 2018). Dasho Karma Ura, President of the Centre for Bhutan Studies and Gross National Happiness Research, stated, "It is important that hydropower, which is [a] key issue for the Bhutanese people also be looked at more quickly...public opinion in Bhutan was beginning to question the viability of the debt incurred by the projects" (Ibid).

In 2016, New Delhi-based Vasudha Foundation published "A Study of the India-Bhutan Energy Cooperation Agreements and the Implementation of Hydropower Projects in Bhutan". According to the report, the first major challenge faced by the Bhutanese is hydropower project-related debts. In the Financial Years 2016-17, the country had "₹118.77 billion of outstanding Indian Rupees loans. Of the total Rupee debt, 94.11 per cent were outstanding public debt on hydropower projects while 5.89 percent represented debt taken to finance BOP [Balance of Payments] transactions with India (the Government of India line of credit)" (Royal Monetary Authority of Bhutan, Government of Bhutan). It is being maintained that the three ongoing projects - Mangedchhuand Punatsangchhu I and II would put Bhutan under about ₹12,300 crore rupees of debt. This accounts for 77 per cent of the country's total debt and is about 87 per cent of its GDP (Haider, 2017).

There is also a concern over the emergence of an auxiliary Indian economy in Bhutan. The massive influence of Indian hydropower companies and their participation in the accompanying sectors are being questioned by the Bhutanese. For example, Larsen \& Toubro, Gammon India and Hindustan Construction Companies have also set up stone crushing industries, besides their contract in the Punatsangchhu hydropower project (Bisht, 2012). 
The hydropower sector was supposed to provide jobs to the local population, however, according to the Vasudha Foundation report, they have not. According to a release by the Indian Embassy in Bhutan in 2015, "There are about 60,000 Indian nationals living in Bhutan, employed mostly in the hydro-electric power and construction industry. In addition, between 8,000 and 10,000 daily workers enter and exit Bhutan every day in [the] border towns" (Vasudha Foundation, 2016). The rate of unemployment in Bhutan was 2.1 per cent in 2013 and 2.9 in 2014 (Ibid). At many project sites and after the start of their operations, some of the locals allege that they have not been provided with the necessary training to take up jobs in the sector(Ibid). On the contrary, the Royal Monetary Authority Report of 2016-17 says that the hydropower sector has contributed to generating direct and indirect employment opportunities for the Bhutanese. The report states, "As of June 2017, there are 3,950 (851 are key officials and staff) employees in PHP I (Punatsangchu Project -I), 6,942 (857 key officials and staff) in PHP II (Punatsangchu Project -II), and 4,857 (509 key officials and staff) in MHP (Mangdechhu Project). There are about 1,687 employees under DGPC (Druk Green Power Corporation), mainly for operation and maintenance of generating hydro plants, and about 2,500 under Bhutan Power Corporation for the construction and maintenance of electricity transmission line in Bhutan" (Royal Monetary Authority of Bhutan, Government of Bhutan 'Annual Report 2016-17', 50).

\section{Conclusion}

This paper has looked at the history of relationships between India and Bhutan which exists since ancient times. In past, there were certain hiccups but the relations never deteriorated. At present, although the two states share cordial relations, there are certain areas of concerns. One of them, as discussed in this paper, is India's investments and engagements in Bhutan's hydropower sector. Reduction in grant's ratio by India to Bhutan and inordinate rise of hydropower debts have made many Bhutanese a bit wary about such projects. There is a prevailing undercurrent among a section of Bhutanese that India exploits their hydropower resources for its own benefits (See Lamsang, 2019). 
In South Asia, almost all neighbouring countries have been attracted towards China because of its economic might, capability to make huge investments and grant loans. India is trying to make similar offers to its neighbours, though less in quantity. As India cannot not match China in terms of money, it must accommodate the interests and address the concerns of neighboring countries.

\section{References}

Bisht, M. (2012, 16 July). The rupee crunch and India-Bhutan economic engagement. IDSA. Retrieved from https:// idsa.in/ issuebrief/ TheRupeeCrunchandIndiaBhutanEconomicEngagement_MedhaBisht _160712. Accessed on 3 April 2018.

Economic and Political Relations Between Bhutan and Neighbouring Countries A Joint Research Project of The Centre for Bhutan Studies (CBS) and Institute of Developing Economies, Japan External Trade Organization (IDE/JETRO). Retrieved from http:// www.bhutanstudies.org.bt/ publicationFiles/ Monograph/ monoEcnmc-Pol-Rel-Bt-Nghbrng.pdf. Accessed on 15 July 2019.

Haider, S. ( 2017, 6 September). Hydropower debt, delays biggest challenge in ties with India, say Bhutan officials. The Hindu. Retrieved from http://www.thehindu.com/news/national/hydropower-debtdelays-biggest-challenge-in-ties-with-india-say-bhutanofficials/article19630701.ece Accessed on 2 April 2018.

Karthikeyan, A. (2017, 1 October). The brief supremacy of mountain king. DNA. Retrieved from http://www.dnaindia.com/analysis/columnthe-brief-supremacy-of-a-mountain-kingdom-2549548. Accessed on 2 April 2018.

Kohli, M. (1993). From dependency to interdependence: A study of Indo-Bhutan relations. New Delhi: Vikas Publishing House Pvt Ltd.

Lamsang, T (2017, 26 July). More than Doklam issue, Bhutan worries about hydropower deficits. Tenzing Lamsang. The Indian Express. Retrieved from http://indianexpress.com/article/opinion/morethan-the-doklam-issue-bhutan-worried-about-hydropower-deficits4768598/ Accessed on 27 July 2017.

Lamsang, T. (2019, 23 March). Sunkosh stuck due to differences between Bhutan and India on implementation modality. Retrieved from https:// thebhutanese.bt/sunkosh-stuck-due-to-differences-betweenbhutan-and-india-on-implementation-modality/. Accessed on 16 April 2019.

Mathou, T. (2004). Bhutan China relations: towards a new step in Himalayan politics. Bhutan Studies. Retrieved from http:// www. 
bhutanstudies.org.bt/publicationFiles/ConferenceProceedings/Spide rAndPiglet/19-Spdr\&Pglt.pdf Accessed on 17 September 2018.

Ministry of External Affairs, Government of India. (2007). "India-Bhutan Friendship Treaty". Retrieved from https://mea.gov.in/ Images/pdf/india-bhutan-treaty-07.pdf. Accessed on 27 March 2018.

Ministry of External Affairs, Government of India. (2012). India-Bhutan Relations. Retrieved from 'http:// mea.gov.in/ Portal/ ForeignRelation/Bhutan-February- 2012. Accessed on 27 March 2018.

Ministry of External Affairs, Government of India. (2017). Press Statement on Doklam disengagement understanding. Retrieved from http:// www.mea.gov.in/presreleases.htm?dtl/28893/ Press_ Statement_ on_Doklam_disengagement_understanding. Accessed on 21 May 2018.

Ministry of External Affairs, Government of India. (2018, December 28). Joint press statement on the State visit of Prime Minister of Bhutan to India". Retrieved from https://www.mea.gov.in/bilateraldocuments.htm?dtl/30853/Joint+Press+Statement+on+the+State+Vis it+of+Prime+Minister+of+Bhutan+to+India+December+28+2018.

Accessed on 22 January 2019.

Ministry of Foreign Affairs of the People's Republic of China. Assistant Foreign Minister Kong Xuanyou Visits Bhutan, 2018/07/24. Retrieved from https://www.fmprc.gov.cn/mfa_eng/wjbxw/t1580397.shtml. Accessed on 3 September 2018.

Ministry of Foreign Affairs, Royal Government of Bhutan "Press Release". (2017, June 29). Retrieved from http://www.mfa.gov.bt/?p=4799. Accessed on 3 September 2017.

Ministry of Foreign Affairs, Royal Government of Bhutan. "Press Release". (2016, March 5). Retrieved from http:// www.mfa.gov.bt/?p=3522. Accessed on 17 September 2018.

Outlook. (2017, 2 July). Bhutan to supply hydropower to Bangladesh via India. Retrieved from https:// www.outlookindia.com / newsscroll/ bhutan-to-supply-hydropower-to-bangladesh-via-india/1090541

Accessed on 19 June 2018.

Phuntsho, K. (2013). The history of Bhutan. Noida: Random House.

Ranjan, A. (2018a). India-Bhutan hydropower projects: cooperation and concerns. Retrieved from https://www.isas.nus.edu.sg/wpcontent/uploads/2018/10/Working-Paper-No.-309-India-BhutanHydropower-Projects-2.pdf

Ranjan, A. (2018b). Power shift in Bhutan and its implications for India. Retrieved from https://www.isas.nus.edu.sg/wp-content/ uploads/ 2018/09/ISAS-Insights-No.-516-Power-Shift-in-Bhutan-and-itsImplication-for-India.html 
Ranjan, A., \& Losheini, R. (2018). India-Bhutan: affirming 50 years of relationships Retrieved from https://www.isas.nus.edu.sg/wpcontent/uploads/2018/11/ISAS-Working-Paper-310-India-BhutanAffirming-50-Years-of-Relationship.pdf

Robinson, F. (1989). The Cambridge Encyclopedia of India, Pakistan, Bangladesh, Sri Lanka, Nepal, Bhutan and The Maldives. Cambridge: Cambridge University Press

Roy, S. (2018, 24 July). China minister arrives in Bhutan on first top-level visit after Doklam. The Indian Express. Retrieved from https:// indianexpress.com/article/india/china-minister-arrives-in-bhutanon-first-top-level-visit-after-doklam-5272450/. Accessed on 24 July 2018.

Royal Monetary Authority of Bhutan, Government of Bhutan, Annual report 2016-17. Retrieved from https:// www.rma.org.bt/ RMA\% 20Publication/Annual\%20Report/annual\%20report \%20\%2020162017.pdf on 28 March 2018.

Shubham, (2014, 18 June). Understanding India-Bhutan relations. One India. Retrieved from https:// www.oneindia.com/ feature/ understanding-india-bhutan-relations-1467521.html Accessed on 27 March 2018.

Stobdan, P. (2017, 14 July). India's real problem lies in its Bhutan policy, Not the border' The Wire. Retrieved from https:// thewire.in/ diplomacy/india-china-doklam-real-problem-bhutan. Accessed on 2 April 2018.

Tala Hydroelectric Project. 2018. Retrieved from https://www.powertechnology.com/ projects/tala/ . Accessed on 15 June 2019.

The Bhutanese. (2015, 13 June). Indian media should do their homework on Bhutan's 2003 Operation All Clear. Retrieved from http:// thebhutanese.bt/indian-media-should-do-their-homework-onbhutans-2003-operation-all-clear/.Accessed on 27 March 2018.

Vasudha Foundation. (2016). A study of the India-Bhutan Energy Cooperation Agreements and the implementation of hydropower projects in Bhutan. Retrieved from http://www.vasudhafoundation.org/wp-content/uploads/Final-Bhutan-Report_30th-Mar2016.pdf. Accessed on 28 March 2018.

\section{Endnotes}

1 Sikkim became a part of India in May 1975.

2 From 1945 to 1971 it was Republic of China which was member of the United Nations. 
${ }^{3}$ At some places it is mentioned that the rate is 9 per cent. See 'Tala Hydroelectric Project'. op cit. 